\title{
"Nature caprices are finally defeated!": reclamation politics and practices in Latvia during the era of modernism
}

\author{
Anita Zarinaa ${ }^{1,1}$, and Ivo Vinogradovs ${ }^{1}$ \\ ${ }^{1}$ University of Latvia, Faculty of Geography and Earth Sciences, Department of Geography, \\ Riga, Latvia
}

\begin{abstract}
Soviet agro-polders, as ideological and highly technological assemblies, were among the first ones to signify the productivism era in the rural landscape of the Baltic republics and the modernisation of Soviet agriculture there. At the time of autocratic reigning of productivist ideas, polders were a testimony to productivity - the means to disband with the unproductive past and demonstrate the Soviet Union's scientific and technological supremacy over the traditional ways of managing the wetlands. The establishment of polders took place during two different periods of Soviet agricultural developments. The first phase occurred as part of Khrushchev's reforms, whereas the second was implemented under Brezhnev's reclamation programme. Whereas the former was linked to recovery from stagnant Stalinist schemes by improving the conditions of marginal areas and poor collective farms, the latter, in the context of Latvia and the other Baltic Republics, entailed extensive works on what was called the "northern strategy of drainage, liming and so on". The paper, building on case studies, wider political contexts and local situations, explores the drainage movement and traces the formation of agro-polders, unfolding the practices of the Soviet agricultural ideology in action.
\end{abstract}

\section{Introduction}

The politics and actions of agricultural modernization, conceptualized also as the productivist agricultural regime [1, 2], in Latvia already took place during the nationstate period, and became particularly important during the Ulmanis authoritarian regime in the 1930s. Through the Soviet period, these politics were part of the agricultural ideology described as "authoritarian high modernism" [3], which could be characterized as arrogant faith in the program of technical rationality that privileges central, explicit and technical knowledge over local, tacit and practical know-how which eventually reigned during Soviet Latvia. Tilzey [4] referred to this era as "political" productivism due to the "corporate" relationship between the State and the agriculture sector. In the Soviet

\footnotetext{
${ }^{1}$ Corresponding author: anita.zarina@lu.Iv
} 
case, the State's (or Party's) relations with and influence upon the agriculture sector was even greater [5].

In the rural landscape of Latvia, one of the most exceptional remnants of this "political" productivist era are agro-polders - ideological and highly technological agroindustrial assemblies. Such large agricultural land conversion ventures, although petty to compare with the transformations of nature elsewhere in the Soviet Union [6], in the region were employed for the first time [7, 8]. In the 1950-60s, ten thousand hectares of diverse wetlands at the SW coast of Latvia were converted to homogenous agroindustrial complexes specializing in grass meal production. From the present vantage point, this reckless and ecologically ignorant [7, 9] drainage continued up until the 1990s turning for about 50 thousand hectares of swamps, marshes and floodplains into agropolders. Approximately the same size of land was converted to polders in Lithuania as well, mainly in the Nemunas delta [10], while, in the Southern part of Estonia, a much lesser 7.6 thousand hectares of wetlands [11] were constructed as polders.

Our study focuses on the ideological contexts of wetland reclamation during the era of "political" productivism that led to the construction of agro-polders in Latvia. We used field observations, qualitative analyses of literature, media and various documents, as well as particular case studies to explore the transformation and uses of these agro-wetlands.

\section{Wetland reclamation and the modernism ideas in the interwar period}

Drainage for agricultural purposes in the territory of Latvia that changed the customary practices of everyday land management and also reshaped considerably the landscape of settlements started only somewhere around the end of 19th century, when productivity of ameliorated lands, according to the professor in agronomy Vārsbergs [12], was widely acknowledged and the drainage was actively encouraged. Using the particular language of expression at that time, Vārsbergs [12] denoted swamps as the "suppurating boils on our land" and that all efforts should be put to understand their genesis and eventually "to cure the land". Apart from the small yet growing scale, drainage by open ditches in the 1920s and projects on lowering the water level in lakes were intended for gaining additional pastures and meadows. It is estimated [13], that by 1914, there had been drained approximately 10-15 thousand hectares of agricultural land, mainly by open ditch systems. Indeed, a petty number to compare with the estimates for potential amelioration exigencies in $1939-1.5$ million hectares in agricultural land. These figures were actually reached by the time of the end of the Soviet regime in 1980 s.

During the interwar period, the national drainage plan was carried out slowly but surely - land amelioration communities were established, numerous rules by the Cabinet of Ministers were issued and support systems had been put into practice [14]. Similar to the drainage plans during dictatorial regimes in Europe, described by Renes and Piastra [15], Ulmanis' plans for drainage entailed also symbolic national meanings. In the late 1930s, for example, a national showpiece project was started to create new settlements in drained wetlands wherein to "settle the growing nation in the future" [14]. In swampy lowlands near Riga, a 220ha bog was drained to build the first village-type settlement of 17 households for Liberation fighters, called Uzvaras Lidums (Victory Clearing). 
Another showpiece project was the engineering of a polder in the Babīte wetlands that lie in between the capital of Rīga and the resort town of Jürmala and for the commuters would have represented the landscape of prosperous (drained and productive) Latvian farms. A full report about the Babīte polder was published in 1939 [16], the same year polder works actually started, containing information about the purposes of engineering works, the explicit technical details, expenses and estimated benefits. The arguments for the construction of the Babite polder were similar to the ones used later in Soviet times: the control of seasonal floods and the need for productive hay meadows for livestock-oriented farming developments. However, the Babīte polder's implementation works ceased soon due to WW2 and rearrangements in the political arena. The polder was finally constructed in the late 1970 s serving as an important horticulture area on the outskirts of Riga for growing vegetables, mainly carrots and cabbages. Nowadays, mainly due to the suburbanization and agricultural marginalization processes, these are largely abandoned lands with some suburban developments.

\section{Becoming productive: the Soviet drainage boom}

\section{Striving for productivity}

Soviet agriculture around the 1950s could be characterized as "the orphan of the Stalin period", because of the large investments in other economic sectors (mainly in industry) and in urban developments [6]. For example, the average wheat yield in the Soviet Union in 1950 was 8.1 quintals per hectare, in the Latvian Republic 10.01, while, for example, in Denmark wheat production the same year reached 35.1 quintals per hectare [13]. By Scott's [3] account, since Stalin's dictatorial regime, the yields of many crops were stagnant for the next half of the century, regardless of the various reforms launched after Stalin's death. The official reason for such a decline of productivity in Soviet Latvia was the drainage condition of agricultural lands, but, as Boruks [13] ascertained, it was, in fact, the lack of educated and knowledgeable agronomists. Khrushchev's progressive agro-politics at that time were oriented mainly towards the virgin lands scheme, the expansion of new agricultural areas in the Far East, while the old agricultural lands were left out of the improvement focus [6].

Productivity ratings, institutionalized through five-year plans, and the so-called front-rank position at that time became the intrinsic aim for kolkhozes and sovkhozes, sustained through the confidence in socialist competition. Consider, for example, a grotesque picture of how to increase the productivity of sugar-beet yields in the Priekule Sovkhoz, published in the Latvian SSR newspaper Druva in 1962 [17]. The problem was related to the previous year's sugar-beet yield that was insufficient compared with the overall norms. After a scrupulous investigation, it was ascertained that the matter lay in "the hardest part of the sugar beet growing", that is, in their weeding. In order to avoid this mistake, the whole collective body was mobilised and everyone, including housewives and leaders, were forced to take part in the weeding process, having a specified part of the field tagged with their names for collective surveillance. Regardless of the cool summer, the yield in that year exceeded all expectations thus affirming Khrushchev's thesis on importance of the "human attitude" towards cultivation practices.

Certainly, all of these stories, especially during the Stalin and Khrushchev periods, contained a lot of rough propaganda, but, in the end, they clearly explain how the 
apparatus functioned at the time - fulfilling the particular goals of collective farms that corresponded to, as Scott [3] reasons, "a hypothecated, generic, abstract farm ... for which local knowledge, practice, and context were considered irrelevant or at best an annoyance to be circumvented". Whereas the so-called "third-generation" reform, according to Gustafson [6], with Brezhnev's agricultural policy, was the last of the great Soviet industrializing campaigns - it actually acknowledged the problems that Soviet agriculture faced and was oriented towards vast capital investments and training to develop a modern "agro-industrial complex" (to use the Soviet term). This was the period when major landscape changes, especially through mass drainage, came about in Soviet Latvia.

\section{Massive drainage and the construction of polders}

A massive reclamation of wetlands was linked to the livestock farming development that lacked high quality meadowland. According to Strods' analysis on the post-war agricultural condition [18], in the 1950s, many of the well cultivated pastures and meadows were turned into arable land. Wetland drainage for agricultural needs was therefore an answer to this problem supported by a rich profusion of Soviet ideology in the media. "Nature's caprices are finally defeated" or "fertile pastures and tillage will be seized from lakes and rivers". This is how the battle between hostile nature and man, especially regarding polder construction, was represented through countless articles in Soviet Latvia's press. It was also discussed in scientific writings, which at the time were likewise saturated with political ideology. For example, the landscape scientist V. Klanis, in her dissertation [19], acknowledges that one of the most important scientific tasks is to help build the economy of the Soviet Union by understanding the forces of nature and commanding over them for better use of natural resources. Klanis cites Khrushchev's speech at the Politburo's Plenum in 1954, in which he had indicated that in the reclaiming process of new agricultural lands "we don't have to limit ourselves to the eastern lands", and, that "we will need to reclaim the vast areas of river flood-lands, swamps, low productivity meadows and pastures of our northwest regions". Drainage thus became one of the pillars for productivist ideas and actions, but polders, as a technocratic triumph over nature, were a particular ideological showpiece especially in agriculturally marginal lands (naturally poor and/or wet soil areas).

Polder constructions took place during two different periods of Soviet agricultural developments. First was related to Khrushchev's reforms, the second to Brezhnev's reclamation programme. If the former was linked to recovery from stagnant Stalin-era schemes and was oriented towards new crop cultures and arable land expansion [13], the latter in Latvia's context, as well as in the other Baltic Republics, meant the extensive works on what was called the "northern strategy of drainage, liming and so on" (Figure 1) [6]. Drainage became especially extensive after 1966, when the Central Committee of the Communist Party adopted a decree for drainage works to be done with national (i.e., Moscow) funding [7]. According to Dreifelds [20], the territorially small Latvia claimed over $11 \%$ of all Soviet drained land. Furthermore, Melluma [7] has argued that there was indeed no scientific basis for such a scale of land drainage that in 1989 stood at $96 \%$ of all land suitable for agriculture. 


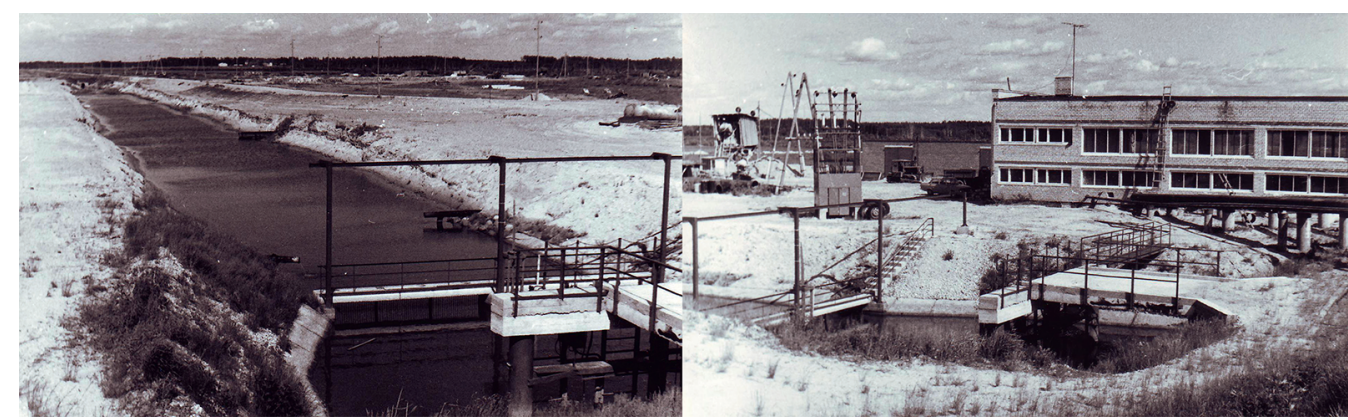

Figure 1. The main canal and pump station of the Silzemnieks polder (along Lake Burtnieki) in 1983. It was the first modernised polder in Soviet Latvia with the system of drainage and irrigation that was controlled by an automatic pump station, a grass meal production unit, as well as all the necessary auxiliary structures for its operation. (Source: Valmiera Local History Museum).

The first polders were constructed in the agriculturally marginal lagoonal wetland area along the Baltic Sea coast, south of the city of Liepāja. These wetlands were transformed into seven polders spanning a total of approximately 10,000 hectares during the first phase of mass drainage in Latvia, that is, in the so-called era of Khrushchev's experiments. The oldest polder, the Tosele polder, was constructed in 1958, the Bernāti polder was built in 1959, and the next five polders were finished there in the 1960s. The smallest of these - the Pape polder (515 hectares), was engineered at the end of the 1960s in a kolkhoz named Uz priekšu! (Onwards!), with a naturally limited agricultural potential. Therefore, the polder was seen as a solution for redeeming the kolkhoz's weak subsistence, and, indeed, both then and now it provides the locals with extra, albeit still poor, agricultural lands with artificially-made sandy peat soils. The former kolkhoz's chairman Sūnākslis [21] in his recollections stresses the importance of his insistence in the construction of the polder. His requests for the amelioration project were rejected several times at the beginning, although it was estimated that they would gain approximately 100 hectares of arable land, about the same for pastures and about 300 hectares for meadows. In the words of the former chairman, the main, unofficial argument from the officials was that the constructed polders in Nĩca (i.e., Tosele and Bernāti) did not provide the expected output, although in the media at that time these first polders were depicted as a great success, stressing the amount and speed of the amelioration works carried out, mechanization progress and the gained fertility of ameliorated lands. And this is how the productivist landscape of the Nica Sovkhoz was portrayed a bit later in the 1970s, by a reporter of the official party's newspaper Cinna:

We don't have to traverse the whole Nīca Sovkhoz to fully breathe in the scent of blossoming lilacs mixed with the ones of work. On the left side of the highway a tractor passes over a field of the succulent sward, sprinkling chemicals, a bit further a soil loosener enriches the field wherein a cabbage crop will grow, but at the polder meadows we hear the scythes of the mowing machines [22]. 


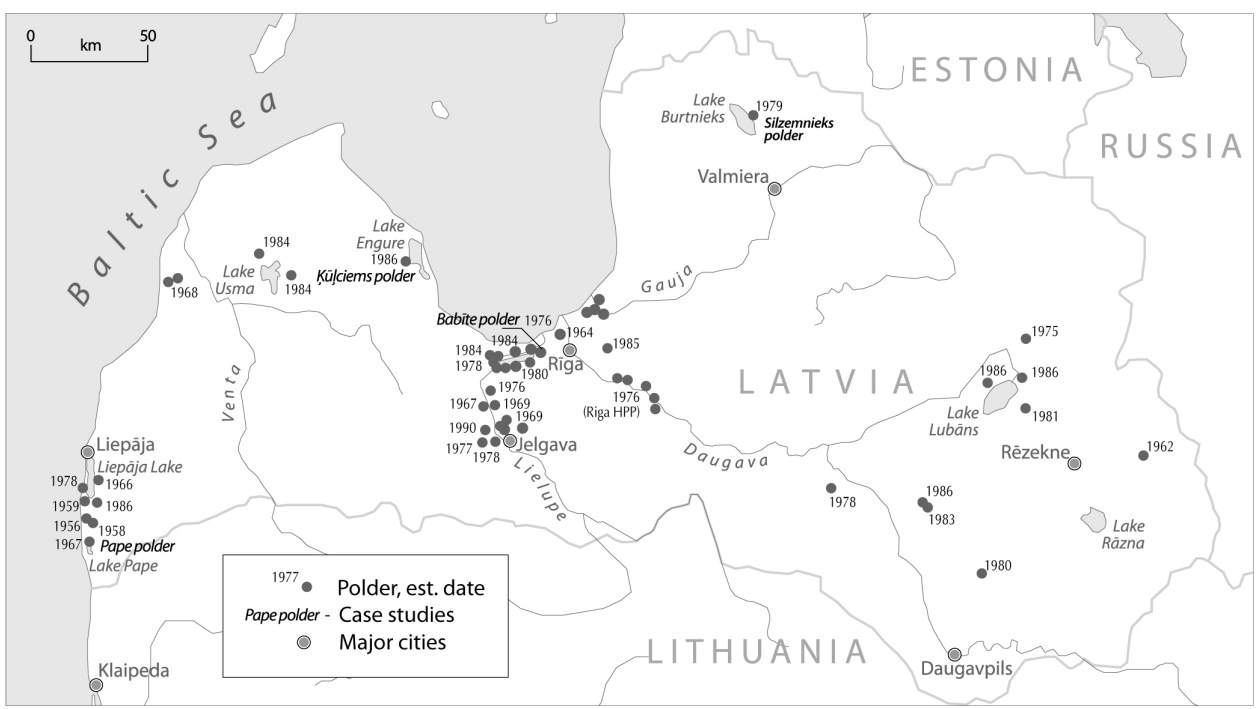

Fig. 2. Location of Latvia's polders and their establishment dates (for the majority of polders the dates indicate completion of the construction works). As case studies are indicated polders that are mentioned in the paper.

Drained agro-wetlands, including altogether 53 agro-polders with the average size of a thousand hectares (Figure 2), were usually oriented toward bailed hay and grass meal production. Chemicals, such as ammonium polyphosphate fertilizer solutions, phosphorus and potassium were heavily used there; nitrogen was used after each cutting that during the season took place 3 to 4 times, in some places starting already in mid-May [8]. These ameliorated peat soils were also considered suitable for the cultures of potatoes, cabbage, sugar beet, and timothy-grass seeds [23]. This was the case with the Kū çciems polder of the kolkhoz Lāčplēsis (Bear-slayer - a hero from a national epic) that specialized in the production of seed potatoes - supplying this product to all of the Northwest regions of the USSR. The Soviet agricultural modernization and intensification movement reached the marginal lands of Kū lciems in the late 1960s. In order to employ heavy machinery and to develop large fields suitable for technological advantages, intense land reclamation projects were created. People from scattered farmsteads were moved to village centres, field size dramatically increased, deep ditches were dug with heavy machinery, and a dense drainage system was implemented (Fig. 3).

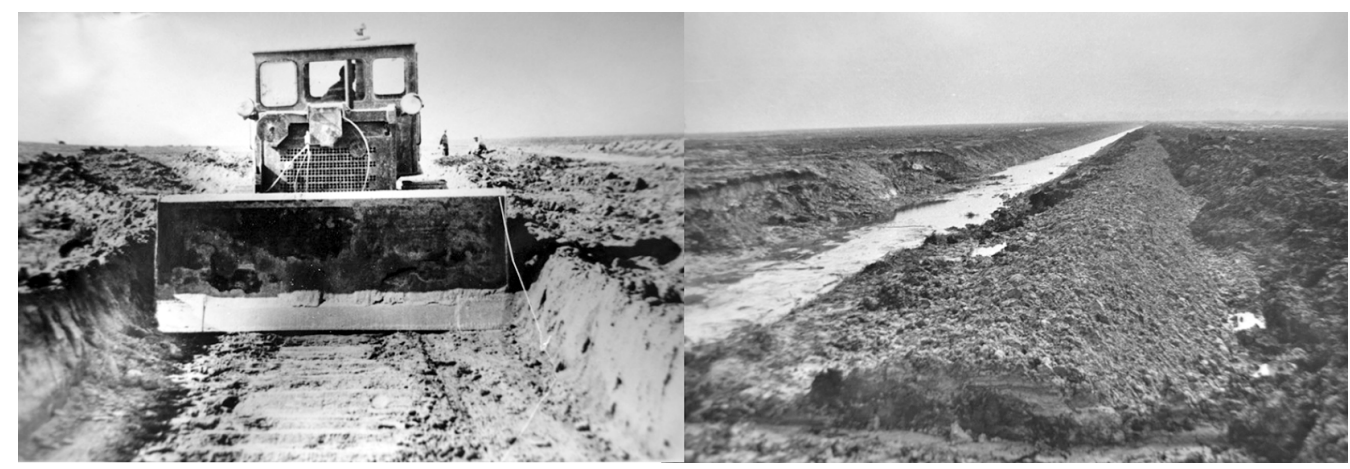

Fig. 3. Drainage of the Ķụ̄ciems wetlands in the late 1960s (Source: Museum of Latvia's Agriculture). 
Regardless of the changes in field size and cultivation techniques, kolkhoz workers still faced serious problems, as a combination of a high water table and both insufficient, and malfunctioning drainage (typically because of superficial and slapdash works) did not allow implementing all the agricultural instructions of intensification and modernization. In the early 1980 s, a polder was seen as a panacea for the fulfilment of the Party's agricultural course there, for locals, a "longed impulse for collective striving", as a republican newspaper stated in 1986 [24]. The Kū l̦ciems polder is one of the last polders built in Latvia, but due to the collapse of the Soviet regime, the works on the polder enlargement remained uncompleted. All in all, the K̦ūḷciems polder on one hand exemplifies the ineffectiveness of Soviet land use practices in a long-term perspective, on the other, fully accounts for the Soviet industrial agriculture struggles and short-term successes achieved through prohibitive costs in a productivist regime.

\section{Conclusions}

The course of modernist ideas and actions to adjust Latvia's rural landscape for productivist agriculture started at the end of the $19^{\text {th }}$ century. One of the most "preproductivist" Latvian writers, E. Virza, at the beginning of the $20^{\text {th }}$ century already acknowledged [25] the progressive movements and breaks with the past, particularly through the drainage movement and thus the inevitable loss of traditional rural landscapes. During the first nation-state, the so-called Ulmanis regime strove for gaining more agricultural lands by draining wetlands, turning meadows into arable lands and clearing forests, while in the Soviet period the emphasis lay on improving the existing agricultural lands with more industrial means. Although both regimes urged for high yields, the means to reach these ends were utterly different. During Soviet times, decisions were mainly based on abstract agro-scientific findings or pure ideology and were implemented as if the land was an experimental ground usually with no in-depth investigation of place, ecological or historical contexts and mutedly tolerated by society $[3,7,13]$. Undoubtedly, at the time of the autocratic reign of productivist ideas, agropolders were a testimony to productivity - the means to disavow the unproductive past and to demonstrate the Soviet scientific and technological supremacy over nature and traditional ways of managing wetlands [8]. Today these agro-polders are one of the main still-functioning signatures of the Soviet productivist landscape. The majority of these polders are now as if outside their own time, outmoded both by their idea and practicalities and represent the short-living productivist ensembles that were constructed "in the blinding lights of the century", citing the words of Agamben [26] on the contemporaneity, that is, in the era of modernism as some sort of salvation promised by technological progress.

\section{Short resumes}

Anita Zaringa, $\mathrm{PhD}$, is an assistant professor in geography and researcher at the University of Latvia (Riga). Her main research interests are landscape history and cultural geographies of landscape, landscape role in national identity and rural and urban landscape planning. Her most recent publications discuss the role of path dependency in landscape development, amber employment in state semiotics during the $20^{\text {th }}$ century. Her latest research on Soviet landscapes and post-Soviet landscape heritage was published in a paper focusing on the development pathways of former Soviet agro-polders. 
Ivo Vinogradovs, $\mathrm{PhD}$ candidate in geography, is a researcher at the University of Latvia (Riga). His main research interests are landscape ecology, land-use planning and ecosystem services analysis. His latest research has dealt with the Soviet inheritance regarding the processes of land use change and agricultural marginalisation of agro-wetland (polder) landscapes. His most recent publications discuss the driving forces of landscape change at a local scale.

\section{References}

1. LOWE, P.; MURDOCH, J.; MARSDEN, T. et al. 1993. "Regulating the new rural spaces: the uneven development of land", Journal of Rural Studies, vol. 9: 205-222. DOI: https://doi.org/10.1016/0743-0167(93)90067-T

2. WILSON, G.-A. 2001. "From productivism to post-productivism... and back again? Exploring the (un)changed natural and mental landscapes of European agriculture", Transactions of the Institute of British Geographers, vol. 26: 77-102. DOI: https://doi.org/10.1111/1475-5661.00007

3. SCOTT, J.-C. 1998. Seeing Like a State: How Certain Schemes to Improve the Human Condition Have Failed, New Haven, Yale University Press.

4. TILZEY, M. 2000. "Natural areas, the whole countryside approach and sustainable agriculture", Land Use Policy, vol. 17: 279-294.

DOI: https://doi.org/10.1016/S0264-8377(00)00032-6

5. ARMSTRONG, J.-A. 1976. Ideology, politics, and government in the Soviet Union: An Introduction, New York, Praeger.

6. GUSTAFSON, T. 1981. Reform in the Soviet Politics: Lessons of recent policies on land and water, Cambridge, Cambridge University Press.

7. MELLUMA, A. 1994. "Metamorphoses of Latvian landscapes during fifty years of Soviet rule", GeoJournal, vol. 33, p. 55-62.

DOI: https://doi.org/10.1007/BF00810136

8. ZARIN,A A., VINOGRADOVS I., ŠĶIN̦ĶIS P. 2018. "Towards (Dis)Continuity of Agricultural Wetlands: Latvia's Polder Landscapes After Soviet Productivism”, Landscape Research, vol. 43, n 3: 455-469.

DOI: https://doi.org/10.1080/01426397.2017.1316367

9. RYDÉN, L., 2012. "The Baltic waterscape - lakes, wetlands, rivers and the sea", in L. Rydén, I. Karlsson (eds.), Rural Development and Land Use, Uppsala, Uppsala University: 58-70.

Retrieved from: http://urn.kb.se/resolve?urn=urn:nbn:se:uu:diva-193849 [available on 14 March 2019].

10. BASTIENE, N., SAULYS, V., 2007. "Analysis and evaluation of maintenance expenses of polder systems in Nemunas lowland during the last decade", Vandens ūkio inžinerija: mokslo darbai = Water management engineering: transactions, vol. 31, $\mathrm{n}^{\circ}$ 51: 102-110.

Retrieved from: https://vb.asu.lt:443/ASU:ASU:ELABAPDB6224406 [available on 14 March 2019].

11. IITAL, A., 2012. "Landscape and landscape history", in L. Rydén, I. Karlsson (eds.), Op.cit. [9]: 23-38.

Retrieved from: http://urn.kb.se/resolve?urn=urn:nbn:se:uu:diva-193840 [available on 14 March 2019]. 
12. VĀRSBERGS, J. 1923. Pḷavas un ganības [Meadows and Pastures], Rĩga, Lauksaimniecības departaments.

13. BORUKS, A. 2003. Zemnieks, zeme un zemkopība Latvijā: No senākiem laikiem İ̃dz mūsdienām [Peasant, Land and Agriculture in Latvia: From the oldest times until now]. Jelgava, Latvijas Lauksaimniecības universitāte.

14. ZARIṆŠ, J. 1940. "Vispārējie lauksaimniecības veicināšanas darbi un pasākumi”" [The works and arrangements for agricultural facilitation], in V. Grinens (ed.), Latvijas zeme, zemnieki un viṇu darbs. Rĩga, Lauksaimniecības pārvaldes izdevums: 307-354.

15. RENES, H., PIASTRA, S. 2011. "Polders and Politics: New Agricultural Landscapes in Italian and Dutch Wetlands, 1920s to 1950s", Landscapes, vol. 12: $\mathrm{n}^{\circ} 1: 24-41$.

DOI: https://doi.org/10.1179/lan.2011.12.1.24

16. VALDENS, K. 1939. "Babītes polders senajā Lielupes gultnē" [Babīte polder in the ancient riverbed of Lielupe], Pašvaldību darbinieks, 1 April: 331-336. Retrieved from https://periodika.Indb.Iv [available on 18 March 2016].

17. KALVE, J. 1962. "Pirmrindas pieredzi visiem" [Forward experience for everyone], Druva, $\mathrm{n}^{\circ} 16,15$ August. Retrieved from https://periodika.Indb.Iv [available on 31 August 2016]

18. STRODS, H. 1957. Zemkopības sistēmu attīstība Latvijā [Development of agricultural systems in Latvia], Rīga, Latvijas Valsts izdevniecība.

19. KLANIS, V.-J. 1955. Ģeogrāfiskās ainavas Salacas baseina teritorijā [Geographical landscapes in the territory of Salaca River Basin], Dissertation, Rìga, State University of Latvia. Retrieved from https://dspace.lu.Iv/dspace/handle/7/2731 [available on 2 May 2018]

20. DREIFELDS, J. 1996. Latvia in Transition, Cambridge, Cambridge University Press.

21. SŪNĀKSLIS, E. 2012. The ethnographic interview. [Online]. Nīca Municipality homepage. Retrieved from http://www.nica.Iv/wp-content/uploads/2013/09/EmīlsSūnākslis.-G.Vanaga.pdf [available on 30 September 2016].

22. SPINGA, L. 1975. "Un smaržo siena milti" [And grass meal smells], Cinna, n 125, 30 May. Retrieved from https://periodika.Indb.Iv [available on 30 September 2016].

23. RUBENIS, A. 1964. Kā kultivēsim un izmantosim Lubānas zemienes plavas un purvus [How we will cultivate and use meadows and swamplands of Lubāna plains], Jelgava, Latvijas Hidrotehnikas un meliorācijas zinātniskās pētniecības institūts.

24. DRIĶE, B. 1986. "Lāčplēša vārda cienīgs" [Deserving the name of Bear-Slayer], Cinna, $n^{\circ} 256,26$ August. Retrieved from https://periodika.Indb.Iv [available on 8 September 2016]

25. VIRZA, E. 1930. Laikmeta dokumenti [Contemporary documents], Rĩga, Zemnieka domas.

26. AGAMBEN, G. 2009. What is an apparatus?, Stanford, Stanford University Press. 